\title{
The Corruption in Juridical and Criminal Overview, Based on Judicial Practice of Tirana District Court
}

\author{
Aleks Prifti \\ Department of Law, Faculty of Human Sciences, Ismail Qemali University of Vlora
}

Doi:10.5901/ajis.2016.v5n3s1p534

\section{Abstract}

Given the investigative and judicial experience in relation with the issue posed by the investigation and trial of criminal offenses of corruption, I have chosen to treat this figure of crime, which was and is a disturbing phenomenon in the activity of the structures of the state and public administration, performed by employees entrusted with public functions. This crime has affected all the links of government, emerging from different forms of it. Today, in our society, it is a problem too serious for the mere fact that this crime is creating a consistency in its existence and, as a result, the employees of state administration and justice system are distancing themselves from their professional ethics. As a figure of crime, corruption affects all the links of the three powers of the Republic of Albania, so it affects the legislative, executive and the justice system, where the ways of committing acts of corruption depend on the kinds of these powers. The method used in the treatment of the object of this paper is that of analyzing the concepts related to abuse of office and corruption, identifying the motives and circumstances that affect the commission of this crime. The subject of the criminal offense, in the abuse of office (Article 248 of the Criminal Code) and passive corruption (Article 259 of the Criminal Code), it is always special. The subject, as a rule, is sufficient to be in working relationship in state and public bodies. However, it should be noted that the outcome of these actions can be the result of violation of the rights and freedoms of citizens recognized these from Constitution of the Republic of Albania, which the Article 15 states: "The organs of public power, in fulfillment of their duties, must respect the human rights and freedoms as well as contribute to their realization." The methodology used in the realization of this paper is based on the comparison of figure of the crime of abuse of office and corruption at different periods. With the method used, was done an analysis of the criminal offenses of corruption, aiming to highlight the features that characterize these figures as well as comparisons with other criminal offenses that compete with abuse of office and corruption.

Keywords: corruption, abuse of office, judge, prosecutor, administration

\section{Introduction}

The rule of law, its principles and acceptance of the values, means faith in justice. In order to exist the confidence of citizens in the system, the justice system and state administration professionals should be able to provide reliability. They need to have ethical and exemplary professional behavior. Given these special requirements, in this study we have analyzed the integrity of public, judiciary and state administration and how it can be damaged by abuse of office and corruption.

Standing in front of a historical reality very bitter, where the phenomenon of corruption has affected all structures of state and public administration, I want to touch and crust surface, covering fairly well the actions related to abuse of office and those corruptive performed by employees entrusted with state and public functions.

These two crimes have affected all the links of government, appearing in various forms. Today in our society, corruption is posing a problem too serious for the mere fact that this crime constitutes a "cancer" that has penetrated into every link or particle of functioning of the state apparatus in its entirety, but, on the other hand, it has almost destroyed the report of public trust with the state.

The corruption as a key component of organized crime today is not myth or legend, but it is a tangible reality, as it has become a regional, national and globa phenomenon, with frightening proportions. Also, corruption as a very compromising tool in the hands of criminal organizations, regional, national and international, each separately, but also in alliance with each other, it constitutes the main problem and challenge to all institutions, organizations and structures of law enforcement, international police agencies, state and social structures in general, the threat to the democratic system, society, liberties and human rights.

This complicated social, political, legal, criminological and environmental background of occurrence and development of this phenomenon, sensitize and draw attention, in addition to society, politicians and other important 
actors on the one hand, but also creators, researchers in the field of jurisprudence, sociology, criminology on the other hand, with the hope that the Reform in Justice: Law no. 76/2016 dated 07.22.2016 "On some amendments to Law no. 8417", dated 21.10.1998, "The Constitution of the Republic of Albania", as amended, and legal package of 7 laws in implementation of these constitutional amendments, will bring positive results awaited for years by the whole population in Albania.

It is therefore imperative to be treated in detail the corruption in legal - criminal overview, based on the judicial practice of District Court of Tirana as one of the main courts in our country, focusing on active corruption of judges, prosecutors and other officials of justice, referred to article 319 of the Criminal Code and passive corruption (bribery) of judges, prosecutors and other judicial bodies, referred to article 319/c of the Penal Code. The criminal judicial issues arising from the analysis of the investigative and judicial practice of judicial decisions of Tirana's Court for the period 2007 -2012, as well as criminal policy against corruption.

\section{The Corruption in Juridical and Criminal Overview}

The crime of corruption, heavy affects, the economic interests of the people, their morals and conscience, the judicial authority and public confidence, the proper functioning of the state of law, the democracy, the financial system up to the national security of the country. (Albanian newspaper, 2013).

For this reason comes to the fore, firmly combat of this negative phenomenon and taking measures for its prevention.

Fighting this powerful weapon, is effective the criminal legislation of the Republic of Albania which, in accordance with the Conventions and Recommendations of internationals, foresees the criminalization of criminal offenses of corruption and their penalization with criminal sanctions, based on the principles of legality of guilt, criminal responsibility, protection of human rights and fundamental freedoms of individuals in the fight against criminality.

This legislation concerning the criminalization and penalization of corruption has undergone its evolution during the transition period, by completing and toughened constantly the punishment.

After passing Albania on political pluralism, in 1995 came the Criminal Code of the Republic of Albania. In the code were foreseen only four crime figures of corruption. Firstly: proposal for remuneration addressed to an official that carries a state duty (Article 244) and the giving remuneration to an official that carries a state duty (Article 245). In both cases, active subject is itself the citizen and, secondly: the ask for giving bribes (Article 259) and taking bribes (Article 260), where the active subject is the employee who exercises public functions.

If the designation, as well as their content, these criminal provisions were unclear, solid and incomprehensible, regarding the variety of forms of realization of corruption crime and his whole concept.

Besides the above, the analysis highlighted the lack of appropriate legislation; the difficult nature to understand this crime; the special need of structures' training of law enforcement and justice; the difficulties in collecting and managing evidences in a such criminal trial as well the known difficulties of international cooperation, were main factors in the lack of the efficacy of law enforcement structures and justice in the fight against this phenomenon so widespread.

These gaps were filled with legal changes of 2004, Law no. 9275 dated 16.09.2004, based on the Criminal Law Convention on Corruption of the Council of Europe (Strasbourg, 1999), ratified by the Albanian state law no. 8778 dated 26.04.2001.

With this law became the unification of terminology with that of the Convention, replacing the term taking bribes with term "passive corruption" and giving bribes with the term "active corruption" under the influence of globalization on legal language because our people know the words "bribe" or "under the table".

The novelty of these changes consists not only in increasing the criminal sanctions for this offense, but also to expand and involve more active constituent elements of corruption, whether in the public or private sector according to international standards.

However, most importantly was that by the law of 2004 was predicted punishable new criminal offenses:

active and passive corruption in the private sector (Articles 164/a and 164/b);

active and passive corruption of persons exercising public functions (Articles 244 and 259); corruption of high state officials or local elected officials (Articles 245 and 260);

active and passive corruption of judges, prosecutors and other Justice authorities (Articles 319 and 319/ç).

Pursuant to the Additional Protocol of the Criminal Law Convention and Recommendations of the Group of States against Corruption (GRECO), (International juridical acts, 2006) in 2012 and the Law no. 23 dated 01.03.2012, there were other changes and amendments to the Criminal Code, by criminalizing and penalizing criminal offenses of active and 
passive corruption, for the international court judges, juries, domestic and foreign arbitrators (Articles 319/a to 319/e). Currently, the Criminal Code contains 21 articles that criminalize the criminal offenses of corruption. While the European Convention has 13 articles (11 of which are their undervariants). From the appearance of above results that our state has implemented satisfactorily the approximation of criminal legislation with Criminal Convention of the Council of Europe and GRECO's recommendations for combating the active and passive corruption.

In our code, are frequently made over 250 additions and changes, including articles on corruption. (Criminal Code of the Republic of Albania, 1995). Most of them are taken mechanically without studying and consulting. Many of the articles on corruption can be summarized. Italian Penal Code has only 5 articles, Criminal Code of Kosovo - 2 articles. In their formulation, legal technique is not respected.

In the Code were not involved aggravating circumstances of corruption - conducted by a structured group, with constriction, in large proportions. Let us hope that the new Penal Code, which is the need to prepare and fill further.

The active corruption (judges, prosecutors and other justice officials)

From studies of criminal decisions of different levels of the judiciary, evidenced their activity in the trial of criminal offenses of corruption, but there are few decisions (Cases of judges to the Court of Saranda and Lezha) concerning the self-corruption of judges, prosecutors and other justice officials.

For these reasons, I see it necessary to pause in this important aspect of the fight against corruption because it is actual and concern for our state and society, as well as international opinion, which is expressed of judicial corruption.

In a judicial survey conducted by the Center for Transparency and cheaper Information, in cooperation with the British Embassy was included 68\% of the judges of first instance in the whole country (14 of 29 in total) with the participation of $58 \%$ or 117 judges. From 305 in total, are provided the following answers: $25 \%$ of the judges said that the judiciary in Albania is corrupt. Approximately $58 \%$ think that corruption is only perception, while $18 \%$ see the justice system not corrupt. (Gazeta Shqiptare, 2012).

To protect the authority of the judicial power of judges and prosecutors and other justice officials, as well as the moral and interests of citizens, Criminal Code, after legal changes over the years 2004-2013 provides for the punishment of criminal offenses of active and passive corruption (in Articles 319 and following), with the following content:

"The promise, offer or giving, directly or indirectly, of any irregular benefit for himself or for other people, judge, prosecutor or any other employee of judicial bodies to act or not an action related to the task or its function, is punished with imprisonment from one year to four years". (Article 319).

With this criminal provision is placed in special legal protection not only the operation of regular and honest judges, prosecutors or other officials of justice, but also the rights and interests of citizens, not to give money (bribe) or other benefits for the resolution of their judicial issues.

According to Article 319 of the Criminal Code, the criminal offense of active bribery, objectively, is performed when, a bribe-giver provides money or irregularly benefits, directly or indirectly. For example, giving money or other material benefits to driver of the judge or prosecutor, to deliver that to judge or prosecutor to perform or not an act related to the exercise of his duty. (For example dismiss the case, or to change the legal qualification of the criminal offense in favor of the defendant).

For the active corruption of judges or prosecutors or other employees of justice, has criminal responsibility the person, subject of the criminal offense that promises, proposes or gives an irregular profit. In this sense becomes the criminalization and penalization of bribe-giver (the person - general subject of active corruption). According to the study of criminal judgments, of courts in Tirana results that, is not punished any person who has given a bribe (over active corruption), or because they are not detected by the police or are not taken as defendants. Such a practice is wrong, harmful and illegal, because it favorises the spread of active corruption and not its limitation and fight.

\section{Juridical-Criminal Issues, Arising from the Analysis of Investigative and Judicial Practice}

a. The most important problem of the District Court of Tirana is that of the not - analyzation of all elements of figures of the offense of corruption, in close relation with the case object of adjudication. The analysis of the constituent elements of figures of the offense is necessary to conclude, if the defendant is responsible or not for the right and legal designation of criminal offense and punishment.

The essential elements of the figure of criminal offenses of corruption are common, but each figure of the offense has also its features.

The concrete object (the items) that are given and taken in active and passive corruption can be different, with 
the economic values. This includes the money, check, valuable paper, other valuable items and transport tickets, various services, such as transport of goods, provision of residential apartments, rent-free or donation. In the literature discussed if in the subject of corruption enter diplomas, workbooks etc. Given that, with the diplomas of private universities, supplied not only Albanians, but also foreigners. I think there is no place for discussion, but to be accepted as the subject of corruption.

Among the constituent elements of figures of the offense of corruption is important the clarification of the OBJECTIVE SIDE-how is committed the corruption, with active actions or inaction, whether the benefit is given and received before or after the commission of the favorites, in the the interest of the bribe-giver. It is important to clarify the consequences if they are serious or not, and the causal link. By report-study, in Decision no. 679 dated 30.04 .2012 , on the issue of corruption in the private sector, is not clarified the causal link and the defendant was convicted.

Important it is explanation and clarification of the subject of criminal offense of passive corruption because they are special entities. In addition, the analysis whether there are accomplices, who has been mediator. If a person takes money from another to give the judge or prosecutor and appropriates, it is responsible for fraud whereas bribe-giver, for complete attempt of active corruption.

The other element (the objective side) is to specify in the decision that these criminal offenses committed intentionally and for profit. (Elezi, 2009).

The presentation of the elements of figures of the offense, without regard to the fact of the offense in judgment is formal and it has not practical values. Only closely, relating to the subject of the jugement, it has the required effectiveness and proves that the defendant has committed or not the offense of corruption and so bases its criminal liability.

b. On the basis of this analysis of the constituent elements of figures of the offense becomes the fair and accurate legal qualification of concrete criminal act, which serves to distinguish when there is competition or approximate criminal offenses, for example: the corruption to abuse of office.

From the review of criminal court decisions in Tirana, provided many examples of the different application and interpretation of articles of the Criminal Code related to corruption, particularly for distinguishing corruption from abuse of office, and as a result, have brought about changes in the legal qualification of offenses on conviction of defendant.

This issue has no formal legal character, but it has principle character for the rule of law, rendering justice, the protection of human rights and freedoms, especially of defendants. The distinction of the crime of corruption from that of abuse of office has become clear in the doctrine of criminal law (special part) to any lawyer. These crime figures are separately but when the abuse of office accompanied by corruption, then we have their competition.

In the criminal offense of abuse of office, when to the person exercising public functions have brought unjust tangible or intangible benefits, he operates in conflict with the law. While in the offense of passive corruption, the person requests or receives benefits, to perform or not perform an action that is related to the task, but does not act contrary to his duty.

Another problem associated with corruption is the failure to implement regularly the criminal law, specially the impunity of the crime of corruption, notably against the high officials of justice, and the state in general. The causes and factors operating in this direction are different, with objective and subjective character.

The Non-implementation of law and the impunity of the the criminal offense is related to subjective factors, the professional incompetence of judges and prosecutors, the ignorance of the law or wrong interpretation of the provision, because of collision of different provisions and contradictions between them.

The additions and amendments to the Criminal Code are numerous and frequent. Knowing and understanding them is essential. This is achieved by reading the juridical literature of foreign countries, commentaries and through organized trainings in collaboration with law faculties. European standards can not be achieved fully only through legal baggage benefited at University or the School of Magistrates, but requires high professionalism, qualification and continuous study, a genuine European juridical culture.

The irregular enforcement of law and impunity of the crime are the result of political pressure, especially when it comes to high functionaries accused of corruption, a phenomenon often encountered in practice.

The impunity may be the result of outside interference to relatives, acquaintances, friends, comrades that mediate the judge or prosecutor to cease the issue or give innocence, these in Albanian society as a small and numerous links, reflect more on rendering justice by the court, especially against the defendants for corruption, 
consequently the impunity.

In rendering justice from the courts, must prevail: "There are qualities of judges as professionalism, stability and moral principles, character virtues uncorrupt, particularly with regard to the truth and correctness makes them invincible to any attack to contribute in the quality of decision making and the independence of the court". (Sadushi, 2012).

Naturally, noting several factors directly related to the judiciary in combating corruption will be remembered that the decisive factor is the political, serious, effective will of government officials. This factor accompanied and propel other factors that were highlighted above, as well as organizational, educational factors of training judges, prosecutors, etc.

\section{Conclusions}

1. The Albanian public opinion and study report criminal court decisions arrive in an indisputable conclusion: that corruption, as international negative phenomenon poses a concern for Albania in general and the justice system in particular.

2. Fighting corruption in the justice system in a comprehensive manner intended to be hit hard as society plague because heavy damages the morale, conscience, vital interests and human resources, law, the authority of the justice system, the construction and operation of the rule of law, rendering justice, human rights and fundamental freedoms and up to national security.

3. Fighting corruption in the justice system does not become only to get the status of candidate country to the European Union, without underestimating the importance of its policies, but to save the authority of justice and to strengthen the public confidence in it, fighting the crime of corruption linked to organized crime, money laundering etc.

4. Fighting corruption in the justice system is not realized with strong political will, without interruption, in a collective and comprehensive measures preventive, educational, organizational, structural, and through the application of criminal punishment, putting before the criminal responsibility, especially the higer public officials, as well as those of justice.

\section{References}

Summary of the Codes of the People's Socialist Republic of Albania in 1945-1971 years.

The Criminal Code, updated of 2012.

Rakipi, A., Corruption and fiscal evasion.

The Italian Criminal Code 1997.

Elezi, I., (1974), Criminal Law of the People's Socialist Republic of Albania (special part).

Criminal Law of the People's Socialist Republic of Albania, (1983), special part.

Criminal Code updated of 2001.

Elezi, I., (2004), Criminal Law Special Part, Part II edition.

Unifying decisions of the Supreme Court 1992-2002.

II Dirito Penale Italiano, (2005), Torino-Italy.

Pagliaro, A., (2001), I Principi del Diritto Penale, Torino-Italy.

Luarasi, A., The Code of Administrative Procedures.

Practice of District Court of Tirana 2007-2014. 